Удк 070 : 327

\title{
ЗАСТОСУВАННЯ СОЦІАЛЬНО-КОМУНІКАЦІЙНИХ ТЕХНОЛОГІЙ У МІЖНАРОДНИХ ВІДНОСИНАХ
}

\section{Павлюх Марія Василівна}

кандидат наук із соціальних комунікацій, асистент, Національний університет «Львівська політехніка», м. Львів, Україна

ORCID: 0000-0001-5502-8367

mariapavluch1982@gmail.com
Надіслано:

14.03.2019

Рецензовано:

20.03.2019

Прийнято:

10.04 .2019

Проаналізовано роль соціальних медіа (соціальних мереж) у міжнародних відносинах. Виокремлено міжнародні відносини як головного фігуранта світового інформаційного простору. Подано дефініції основних понять, які характеризують застосування Інтернет-технологій у зовнішньополітичній діяльності держави: зовнішньополітична діяльність держави, зовнішньополітична поведінка держави, комунікація в системі міжнародних відносин або зовнішньополітична комунікація держави.

У дослідженні використано комплекс загальних і спеціальних методів: метод концептуального аналізу у визначенні базових характеристик соціальнополітичної комунікації, компаративний аналіз, функціональний аналіз (функції зовнішньополітичної комунікації та діяльності).

Соціальні медіа та Інтернет перетворюються у нову реальність, де головними акторами стають держави. Політичний імідж держави прямо пропорційний іміджеві у соціальних медіа. Популярність держави, дипломатичних установ залежить від відкритості суспільства та просування у соціальних мережах.

Ключові слова: політичні актори; суб'єкти міжнародних відносин; зовнішньополітична поведінка; зовнішня політика; світовий інформаційний простір; соціально-комунікаційні технології; зовнішній імідж.

Pavliuh Mariia, PHD in Social Communication, Lviv Polytechnic National University, Lviv, Ukraine

Application of social and communication technologies in international relations

The role of social media (social networks) in international relations is analyzed. The international relations as the main contributor to the world information space are singled out. Definitions of the main concepts characterizing the use of Internet technologies in the foreign policy activity of the state are given: 
foreign policy activity of the state, foreign policy behavior of the state, communication in the system of international relations or foreign policy communication of the state.

The study used a set of general and special methods: the method of conceptual analysis in determining the basic characteristics of socio-political communication, comparative analysis, functional analysis (functions of foreign policy communication and activities).

Social media and the Internet are turning into a new reality, where the main actors are states. The political image of the state is directly proportional to the image in the social media. The popularity of the state, diplomatic institutions depends on the openness of society and the advancement in social networks.

Key words: political actors, subjects of international relations, foreign policy behavior, foreign policy, world information space, social and communication technologies, external image.

Павлюх Мария Васильевна, кандидат наук по социальным коммуникациям, ассистент, Национальный университет «Львовская политехника», г. Львов, Украина

\section{Применение социально-коммуникационных технологий в международных отношениях}

Проанализирована роль социальных медиа (социальных сетей) в международных отношениях. Выделены международные отношения как главного фигуранта мирового информационного пространства. Даны дефиниции главных понятий, характеризующих применение Интернеттехнологий во внешнеполитической деятельности государства: внешнеполитическая деятельность государства, внешнеполитическое поведение государства, коммуникация в системе международных отношений или внешнеполитическая коммуникация государства.

В исследовании использован комплекс общих и специальных методов: метод концептуального анализа в определении базовых характеристик социально-политической коммуникации, компаративный анализ, функциональный анализ (функции внешнеполитической коммуникации и деятельности).

Социальные медиа и Интернет превращаются в новую реальность, где главными актерами становятся государства. Политический имидж государства прямо пропорционален имиджам в социальных медиа. Популярность государства, дипломатических учреждений зависит от открытости общества и продвижения в социальных сетях.

Ключевые слова: политические актеры; субъекты международных отношений; внешнеполитическое поведение; внешняя политика; мировое 
информационное пространство; социально-коммуникационные технологии; внешний имидж.

\section{Вступ}

Сьогодні важко недооцінити роль Інтернет-технологій у міжнародних відносинах та зовнішній діяльності держав. 3 розвитком Мережі, міжнародні відносини отримали іншу площину взаємодії - віртуальну. Роль соціальнокомунікаційних технологій у світовій дипломатії вагома, оскільки формує позитивні іміджи держав - учасників геополітичних процесів. Мережа перетворюється у центр геополітики і важливих світових процесів. Нерідко національні інформаційні ресурси стають елементом віртуальної війни держав.

\section{Аналіз останніх досліджень}

Маємо велику кількість праць учених, які досліджують взаємозв'язки Мережі зі світовою політикою та міжнародними відносинами: Н. Пінченко, яка досліджує міжнародну Інтернет-комунікацію та соціальні медіа у структурі зовнішньої політики провідних міжнародних акторів; Ю. Половинчака, що вивчає мобілізаційний та маніпулятивний потенціал дискурсу соціальних медіа в умовах перехідного суспільства; О. Лобікова, яка здійснює комплексний аналіз соціальних мереж як феномену інформаційного суспільства та ін.

\section{Формулювання цілей статті}

Мета статті - висвітлити роль Інтернету та соціально-комунікаційних технологій у сучасній міжнародній діяльності. Мета передбачає такі завдання: подати дефініції основних понять, які характеризують застосування Інтернеттехнологій у зовнішньополітичній діяльності держав; з'ясувати взаємозалежність популярності та іміджу держави 3 соціальними медіа; розглянути плюси та мінуси соціальних мереж у міжнародних відносинах.

\section{Виклад основного матеріалу}

Розвиток світового інформаційного мережевого простору дав поштовх до формування нових акторів та учасників зовнішньополітичних процесів. Провідним актором виступає держава, яка здійснює управління двома сферами політики: зовнішньою та внутрішньою. Велику роль відіграють транснаціональні корпорації, які активно співпрацюють з медіа на усіх рівнях: національному, регіональному та локальному, де активно лобіюють інтереси своїх власників. Роль посередників між аудиторією та інформацією відіграють світові медіакорпорації, які відстоюють власні інтереси. Велике значення мають громадські інститути, різні некомерційні організації, які захищають вразливі верстви населення, займаються благодійністю та охороною довкілля, збурюють громадську активність, що може призвести до формування нової державно-політичної ідеології. Через мережу громадські активісти антиглобалістських, пацифістських та екологічних рухів поширюють власні ідеї 
та постійно взаємодіють із аудиторією на глобальному та міжнародному рівнях. Використання Мережі дозволяє багатьом відомим людям поширювати власні ідеї, не зважаючи на кордони, збільшувати масштаби поширеної інформації.

Поняття «зовнішньополітична комунікація» було введено всередині XX ст. представниками Міжнародної комунікативної асоціації. Зокрема, американські дослідники Е.Девідсон та А. Джордж під поняттям «зовнішньополітична комунікація» розуміли діяльність акторів міжнародних відносин (держав), спрямовану на зміну політичної поведінки (інших держав), яку представляли у вигляді моделі зовнішньополітичної комунікації (Pinchenko, 2014, p. 69).

Згодом, дослідники поглибили та видозмінили це поняття в кін. XX ст. Сьогодні зовнішньополітична комунікація вважається суспільно-політичним феноменом, який має різноманітні форми і діє через ефективні механізми та інструменти, щоб забезпечити державні, суспільні чи корпоративні інтереси.

Дослідниця Н. Пінченко (Pinchenko, 2014, р.70) виокремлює важливі поняття, які характеризують застосування соціально-комунікаційних технологій у міжнародних відносинах, зокрема зовнішньополітичній діяльності держав. Серед цих понять такі: зовнішньополітична діяльність держави, зовнішньополітична поведінка держави, зовнішньополітична комунікація держави та міжнародна комунікація. Усі ці поняття застосовують соціальнокомунікаційні технології.

Соціально-комунікаційні технології широко застосовуються уміжнародних процесах та внутрішньополітичній активності держави. Зокрема, зовнішньополітична діяльність держави через технології забезпечує та здійснює вплив на об’єкти зовнішньополітичних інтересів. Зовнішньополітична поведінка держави розглядається як діяльність / бездіяльність держави у контексті міжнародних відносин. Для зовнішньополітичної поведінки держави важливий конкретний історичний період і розвиток системи.

У мережі зовнішньополітична комунікація здійснюється за допомогою каналу для передачі об’єктів від одного актора до іншого. Зовнішньополітична комунікація розглядається у загальній системі міжнародних відносин як форма реалізації конкретних зв'язків. Міжнародна комунікація тлумачиться як система, де головними акторами виступають міжнародні відносини, через які розвиваються: політична взаємодія, економічно-політичне співробітництво та культурні обміни. Міжнародна комунікація використовує важливі інструменти, які здійснюють ефективне регулювання міжнародних та комунікаційних потоків: мас-медіа, соціальні мас-медіа та Мережа, а також активність у дипломатичній, культурній та економічній сферах. 


\section{Павлюх Марія Василівна \\ Застосування соціально-комунікаційних технологій \\ у міжнародних відносинах}

Зарубіжний дослідник А. Кондратов (Pinchenko, 2014a, p. 38) виокремив функції зовнішньополітичної комунікації та діяльності, зокрема такі: пояснювальна, прогностична, синтезуюча, методологічна, практична. Кожна 3 цих функцій забезпечує ефективну роботу зовнішньополітичної комунікації завдяки соціально-комунікаційним технологіям. Зовнішньополітична діяльність через пояснювальну функцію активно розвиває відносини з різними акторами міжнародних відносин, а також здійснює взаємозв'язок у сфері національних інтересів держави: впливу, тактики, забезпечення та організації.

Прогностична функція зовнішньополітичної комунікації дає змогу змоделювати таку тактику держави, яка б реалізувала національні інтереси. Саме ця функція дозволяє розвивати різноманітні канали засобів масової комунікації для ефективного використання у діяльності держави. Синтезуюча функція має на меті досліджувати розвиток комунікаційних каналів у різних державах світу, об'єднувати отримані результати про зовнішньополітичну діяльність цих держав. У системі міжнародних відносин методологічна функція використовує два важливі підходи: функціональний та системно-діяльнісний для вивчення важливих явищ. Практична функція дозволяє накопичувати знання, досвід, створюючи нові комунікаційні канали і широке їхнє застосування у діяльності держави.

у міжнародних відносинах спостерігається взаємозалежність зовнішньополітичної діяльності держави від i присутності у просторі соціальних мереж і міжнародних медіа (Pinchenko, 2014a, p. 103). Інтернет і соціальні медіа перетворилися на політичний інструмент, який використовується для маніпулювання громадською свідомістю та прямого втручання у внутрішні справи суверенних держав. На рівні ООН Інтернет розглядається як інструмент реалізації права особи на свободу висловлення поглядів.

Застосування соціально-комунікаційних технологій важливі для міжнародних відносин. До поняття міжнародних відносин належать важливі аспекти та макроконцепції. Міжнародні відносини розглядаються як оригінальна форма соціальних відносин, яка відображає індивідуальну та колективну суб'єктність авторів. Головне призначення міжнародних відносин у єдності людства: цивілізаційній та антропологічній. Макроконцепції міжнародних відносин такі: політологічна, соціологічна, системна, культурна та комунікативна. Політологічна макроконцепція визнає основним міжнародним актором державу і підтримує тезу про верховенство держави, яка здійснює міжнародне співробітництво. Соціологічна вказує на прямі трансакції держави у міжнародних відносинах. Системна макроконцепція у міжнародних відносинах враховує вторинність міжнародних акторів. Культурна забезпечує національно-культурну ідентичність та культурну «сенситивність» 
у міжнародному співробітництві. Комунікативна розглядається як суспільнополітичний феномен у різних формах, яка здійснюється завдяки інструментам та механізмам позиціонування, щоб на міжнародній арені забезпечити суспільні і корпоративні інтереси.

Під час управління зовнішньополітичною інформацією російський політолог А. Гуменський виокремив важливі інформаційні стратегії держави: експансивну та інтровертну. Перша стратегія притаманна розвинутим країнам ЄC та США, які вирішують свої національні завдання завдяки використанню зовнішніх ресурсів. Інтровертна стратегія характерна для таких країн: Китай, Куба та Північна Корея. У цій стратегії держава самоізолюється від навколишнього середовища і консолідує свої внутрішні ресурси. Інформаційні стратегії здійснюються за належної медіапідготовки i $\epsilon$ балансом між спрямованістю: внутрішньою та зовнішньою. Стратегії змінюються відповідно до: зовнішніх обставин, державних завдань, а також релігійних, геополітичних та національних особливостей.

У цьому контексті необхідно згадати концепцію «м'якої сили» Дж. Ная-молодшого, яка спрямована на посилення американської дипломатії методами широкого впливу на світову громадськість за допомогою традиційних і нових комунікативних засобів, які розмивають кордони між зовнішньою та внутрішньою політикою. Зазначену концепцію у $2011 \mathrm{p}$. дослідник доповнив, увівши поняття «е-сила», яка формується в межах кіберпростору і призводить до зростання взаємозалежності між економічними можливостями і національною уразливістю. На його думку, кіберпростір знищує бар'єри для поширення влади, сприяючи зростанню політичного та економічного впливу за відносно невеликих витрат недержавних суб'єктів і невеликих держав (Pinchenko, 2014a, p. 38).

Зарубіжний науковець А. Багіров відзначивши позитивну оцінку Мережі, та їі розвиток призвів до створення політично-економічної та соціальнокультурної нерівностей, загостривши проблему «цифрового розриву». Проблема «цифрової нерівності» - проблема глобального характеру. Цифрова нерівність розглядається як соціальний феномен, який торкається багатьох країн у асиметричному використанні соціально-комунікаційних технологій. Асиметрія у державах пов'язана із різним рівнем розвитку держави, політики та економіки, освіти, культури. Цифрова нерівність зумовлена високим або низьким рівнем розвитку медіа в державі, а також активною діяльністю громадянського суспільства. Цифрова нерівність проявляється у багатьох проявах: обмеженості населення у доступі до Мережі, до національних інформаційних ресурсів і до інформаційно-комунікативних ресурсів загалом.

Розвиток інформаційних процесів має глобальний характер, однак кожна країна прокладає власний шлях переходу до широкого використання 


\section{Павлюх Марія Василівна \\ Застосування соціально-комунікаційних технологій \\ у міжнародних відносинах}

інформаційно-комунікаційних технологій (IKT) 3 метою трансформації соціально-економічних процесів. Це обумовлюється тим, що, з одного боку, існують загальні проблеми на шляху раціонального використання переваг IКТ, а з іншого боку - кожна країна виходить з наявних можливостей у процесі складного переходу від індустріального до інформаційного устрою (Polovinchak, 2019).

Інформаційно-комунікативні технології широко застосовуються у суспільних (громадських комунікаціях). Завдяки персональним комп'ютерам, мобільним пристроям, користувачі можуть комунікувати один 3 одним, не зважаючи на час та відстань - що є дуже зручним для економії. Соціальнокомунікативні технології роблять доступним актуальну інформацію протягом кількох секунд.

У міжнародній політиці важливе значення відіграють так звані соціальні медіа (Halich, 2010, p. 146), тобто соціальні мережі. Соціальні мережі мають ознаки медіа, оскільки формують громадську думку користувачів Інтернету через сучасні технічні пристрої (мобільні пристрої та комп'ютери). Якщо розглядати мережу, то технологічно, - це такий сайт, який формує навколо себе соціальне середовище, яке має спільні вподобання та інтереси. Велика он-лайнова спільнота може стати соціальною мережею, коли утворюється читачами за тематикою чи зацікавленнями. Он-лайнові товариства створюють професійні мережі, де користувачі можуть шукати людей та роботу.

Тому Інтернету приділяється значна увага у діяльності міжнародних організацій. Уряди азійських, африканських та латиноамериканських держав використовують соціальні медіа для популяризації своєї позиції і завоювання прихильного до себе ставлення з боку світової спільноти. Дипломатична діяльність багатьох країн повинна базуватися на ідеях, а не на експансії, яку критикує світова громадськість.

Сучасні філософські течії: лібералізм та неолібералізм стверджують, що мережа потребує захищеності та вдосконалення у багатьох площинах. Насамперед, це правове регулювання, оскільки досі нема прийнятих законів щодо мережі. Держава намагається ввести обмеження для багатьох користувачів, щоб запобігти кіберзлочинам, а також захистити авторські права. Усі ці проблеми мережі мають моральний та етичний виміри. Будь-які обмеження щодо захисту прав людей повинні мати логічні наслідки, щоб не порушувати балансу у загальному розвитку системи. Ці філософські напрями розглядають мережу як платформу для розвитку транснаціональних відносин, появу нових політичних акторів, міжнародної взаємозалежності у світі.

Російський науковець Д. Пєсков пропонує розглядати Інтернет як простір міжнародних відносин тому, що мережа виступає як (Polovinchak, 2014): 
- світовим інформаційним виміром, в якому присутні нові та традиційні політичні актори, що здійснюють через мережу політичну діяльність і нерідко домінують над міжнародними організаціями та державами;

- об'єкт правових та політичних відносин, оскільки регулює процеси розвитку світової політики у глобальному масштабі і зміцнює світовий інформаційний простір, захищає права особистості і державні суверенітети через мережу;

- технологія, яка формує життя багатьох суспільств, впливає на еволюцію всього людства; соціальна структура, що співіснує із законами, політично-економічними організаціями, традиціями та культурою держав.

Існують думки й про те, що під впливом інформаційно-комунікаційних технологій змінюється співвідношення компонентів традиційної могутності держав, яка визначається на основі володіння інформаційно-комунікаційними технологіями і позиції у сучасному інформаційному просторі. Така ситуація призводить до виникнення нового міжнародного протистояння, коли прагнення однієї держави домінувати у глобальному інформаційному просторі породжує опір і протидію інших (Lobovikova, Melnikov, 2010, p. 155). Таким чином, розвиток Інтернет-технологій призвів до міждержавних протистоянь на рівні глобального інформаційного простору задля захисту національного суверенітету та змін співвідношення державного впливу в кіберпросторі та інформаційному середовищі. Інформатизація спричинила виникнення неформальних міждержавних альянсів на основі спільних інформаційнокомунікаційних інтересів, діяльність яких спрямована на забезпечення єдиного доступу до певних інформаційно-комунікаційних технологій i здійснення єдиної інформаційної політики, зокрема, наголошується на ролі США у сфері створення глобальної інформаційної інфраструктури та інформаційних стандартів (Hryhorova, 2017, p. 94).

На думку європейського дослідника В.Кляйнверхтера, у мережі формуються нові моделі міжнародних відносин. Роль політичних акторів відводиться не тільки державам, а й громадським та комерційним організаціям. Держава, навіть дуже впливова, не завжди ефективно керує процесами глобального інформаційного середовища, оскільки у мережі $\epsilon$ правила, встановлені інтернет-компаніями.

Турецький дослідник О. Шен запропонував поняття «геоінтернет» розглядати як сучасний вимір геополітики, тому що мережа здійснює активний вплив на міжнародні відносини. Для прикладу він подає публікацію документів організацією Wikileaks або революційні події на Близькому Сході під назвою «арабська весна». Відомий спеціаліст у сфері комунікативних технологій Г. Почепцов розглядає інформаційно-комунікативний простір як уявлення про перспективні зміни економічної та політичної сфер, поряд із тим поява нових 


\section{Павлюх Марія Василівна \\ Застосування соціально-комунікаційних технологій \\ у міжнародних відносинах}

медіа супроводжується намаганням держави їх «приборкати», повернувши до існуючого розподілу влади в суспільстві й державі.

Подібна нетрадиційна дипломатія, на думку науковців, відкрила можливості будувати міжнародне порозуміння шляхом комунікацій між дипломатами, державними діячами й політиками та за допомогою безпосереднього звернення громадян до іноземців, обминаючи представників дипломатичних представництв чи уповноважених урядовців. Представництво світових лідерів і провідних дипломатів в Інтернеті перетворилося не лише на елемент персонального престижу, але й престижу їхніх країн. Структури Євросоюзу мають 26 активних сторінок у Фейсбуці та акаунти в інших мережах. Органи багатьох держав і урядовці мають відкриті та активні акаунти в соціальних медіа, включаючи українські державні органи влади на різних рівнях.

\section{Висновки}

Міжнародна політика відбувається у двох площинах: реальній, тобто традиційній та віртуальній, тобто через соціальні медіа. Головними акторами міжнародних відносин стають держави, які намагаються отримати позитивний імідж через мережу, щоб завоювати прихильне ставлення до себе світової громадськості. Поряд 3 тим, соціально-комунікаційні технології мають негативні ознаки, коли стають об'єктом маніпуляцій та інформаційних війн. Залежність держави та ефективність міжнародних відносин прямо пропорційний іміджу у соціальних медіа. Популярність держави та їі дипломатичних установ залежить від рівня просування у соціальних мережах: чим вищий рівень популярності, тим вища довіра до певної дипломатичної установи.

\section{References:}

1. Halich, T. (2010). 'Sotsialni Internet-merezhi ta virtualizatsiia suspilnoho zhyttia' [Social Internet Networks and Virtualization of Public Life]. Sotsiolohiia maibutnoho [Sociology of the future], issue 1, pp. 145-152.

2. Hryhorova, Z. (2017). 'Novi media, sotsialni media, sotsialni merezhi iierarkhiia informatsiinoho prostoru' [New media, social media, social networks hierarchy of information space]. Tekhnolohiia i tekhnika drukarstva [Technology and technique of printing], issue 3 (57), pp. 93-100.

3. Lisovskyi, M. (2005). Fenomen Internetu yak zasib manipuliuvannia svidomistiu $v$ suchasnomu ukrainskomu suspilstvi [The phenomenon of the Internet as a means of manipulating consciousness in the Ukrainian modern society, [online]. Available at: http://novyn.kpi.ua/2005-3-1/04_Lisovskii.pdf [Accessed 10 January 2019].

4. Lobovikova, E., Melnikov, A. (2011). 'Sotsialni merezhi yak fenomen informatsiinoho suspilstva' [Social networks as a phenomenon of the information 
society]. Visnyk Lvivskoho universytetu. Seriia sotsiolohichna [Visnyk of Lviv National University, Series Sociology], no. 5, pp. 154-160.

5. Pinchenko, N. (2014). 'Mizhnarodna INTERNET-komunikatsiia: politolohichnyi analiz' [International Internet Communication: Political Analysis]. Aktualni problemy mizhnarodnykh vidnosyn [Actual Problems of International Relations]. issue 121, part 1, pp. 69-79.

6. Pinchenko, N. (2014a). Sotsialni media v strukturi zovnishnoi polityky providnykh mizhnarodnykh aktoriv [Social media in the structure of foreign policy of leading international actors]. Kyiv: Tsentr vilnoi presy.

7. Polovinchak, Y. (2015). Mobilizatsionnyi i manipulyativnyi potentsial diskursa sotsial'nykh media $v$ perekhodnom obshchestve [Mobilization and manipulative potential of the discourse of social media in a transitional society], [online]. Available at: http://inso.ge/inso2015/wp-content/uploads/2015/07/4-iulia-polovinchak.pdf [Accessed 20 February 2019].

(C) Павлюх М. В., 2019 